Revista Iberoamericana, Vol. LXX, Núms. 208-209, Julio-Diciembre 2004, 891-913

\title{
RESISTÊNCIA E CRÍTICA REVISTAS CULTURAIS BRASILEIRAS NOS TEMPOS DA DITADURA
}

\author{
POR \\ Maria Lucia de Barros Camargo \\ Universidade Federal de Santa Catarina
}

A resistência tem sido uma das principais chaves explicativas para se tratar da literatura e da cultura no Brasil durante a ditadura militar. Nesse período, a palavra "resistir" tem seu sentido potencializado, inclusive pelas metáforas bélicas que transformam editores em partisans, livrarias e revistas em trincheiras, ou poemas em armas, incorporando aos atos culturais plus de sentidos, imersão na historicidade e forma de validação. Resistir culturalmente constituía ato único e legítimo a ser empreendido pela intelectualidade brasileira "progressista" diante do inimigo comum, o regime militar.

Neste cenário dicotomizado, não resistir significava aderir; não ser “progressista”, ou “de esquerda”, significava ser "conservador”, ou "de direita”. Reconhecida como valor dentre as faixas de população mais escolarizadas e politizadas, a resistência irá caracterizar, fomentar e distinguir a produção cultural, cujos produtos passam a desfrutar de um público crescente ou seja, passam a contar, ironicamente, com um mercado em expansão, que dará forte acolhida e prestígio à chamada "imprensa alternativa"1 e às revistas culturais publicadas sob o signo da resistência, partícipes, assim, do processo de modernização capitalista em curso.

Esse periodismo de resistência surge, se fortalece, entra em declínio e desaparece no mesmo compasso de sua eliciadora contra-face, a ditadura militar, que, ao tentar coibi-la, acabou fomendo a melhor parte da produção cultural do período. E por isso mesmo talvez não seja fora de propósito pensar aqueles anos também como “anos eufóricos”, apesar (ou por causa) do "manto negro" da ditadura. Tal paradoxo se explicita na voz do editor Ênio Silveira que, ao rememorar suas atividades à frente da Editora Civilização Brasileira, destaca, com indisfarçável orgulho, sua reação às perseguições sofridas durante a ditadura militar e a legitimação daí decorrente:

\footnotetext{
${ }^{1}$ Kucinski prefere o termo "imprensa alternativa” a "imprensa nanica” (ambos usados à época) como o mais apropriado para designar os cerca de 150 periódicos surgidos e desaparecidos entre 1964 e 1980, "que tinham como traço comum a oposição intransigente ao regime militar”. (XIII) Restringe sua análise aos jornais e seus jornalistas, à questão da imprensa propriamente dita, deixando de abordar revistas como a Civilização Brasileira ou Teoria e Prática, embora mencione Argumento. Tratarei desses periódicos mais adiante.
} 
Marginalizados e perseguidos, nunca nos submetemos. (...) passamos a lançar mão de todos os artifícios intelectuais para continuar nossa antiga luta em defesa de teses democráticas e progressistas. Curiosamente, os 16 anos entre 1964 e 1980 foram aqueles que testemunharam nossa maior glória, pois o arbítrio e a violência tornaram a editora símbolo e baluarte da resistência cultural e democrática para todo o país. ${ }^{2}$ (Félix 77)

Além da atuação pessoal de Ênio Silveira, que fizera de sua editora a mais ativa e prestigiada da época, não há dúvida quanto ao principal elemento simbólico dessa "resistência cultural e democrática": foi o lançamento, em março de 1965, da Revista Civilização Brasileira, marco inaugural da resistência ao golpe militar exercida nas e pelas revistas culturais. ${ }^{3}$ A mesma voz retrospectiva de Ênio Silveira, sem falsas modéstias, diz:

Marco refulgente dessa fase foi a edição da Revista Civilização Brasileira, que teve curso de maio de 1965 a dezembro de 1968, sendo interrompida com a promulgação do Ato Institucional no 5 (...), e ressurgiu, teimosamente, sob o nome Encontros com a Civilização Brasileira, de julho de 1978 a julho de $1980^{4}$ (sic). Considerada nos meios culturais e universitários do Brasil e do mundo inteiro como um padrão de dignidade da intelligentsia brasileira diante das forças do obscurantismo, essa publicação, em suas duas fases, constitui um dos maiores galardões de minha carreira e marcará para todo o sempre a presença da editora na história cultural do país. (Félix 77-78)

Desde o lançamento, a Revista Civilização Brasileira obteve grande sucesso editorial -em apenas 25 dias esgotou-se a tiragem de 10.000 exemplares do $n^{0} 1$ (dobrada no no 2)- apesar do feitio sisudo em formato de livro: mais de 300 páginas de textos densos, ${ }^{5}$ quebrados, aqui e ali, pelas argutas charges de Jaguar e por algumas páginas onde se lêem poemas “de cunho social”, “engajados”.

\footnotetext{
${ }^{2}$ Trata-se do discurso de posse como membro titular do Pen Club do Brasil, pronunciado em 20 de agosto de 1991.

${ }^{3}$ Kucinski considera que o "ciclo alternativo", ou de resistência, se inicia com o lançamento do tablóide humorístico Pif-paf, em junho de 1964, o que é verdadeiro se tomarmos como objeto de análise todo o periodismo cultural. Neste artigo, contudo, tento restringir-me às "revistas literárias e culturais", mesmo que, muitas vezes, as diferenças entre os jornais alternativos e as revistas culturais sejam tênues. Como não há espaço aqui para discutir tais nuances, assumo a autodenominação do periódico como critério classificatório.

${ }^{4}$ A Encontros com a Civilização Brasileira, publicada até 1981, foi definida por Ênio Silveira, no editorial do nô1, como "uma coleção de livros aberta a todas aquelas tendências que a evolução do pensamento social e científico vem configurando como a atual e plurificada face do humanismo contemporâneo. [...] amplia a linha de conduta intelectual que, de 1964 a 1968, cercou de tanto apreço a Revista Civilização Brasileira(...).” (7-8) Comparando as duas séries, é difícil dizer o que faria da segunda uma coleção de livros e não uma revista, e vice-versa.

${ }^{5} \mathrm{O}$ o 1 sai com 303 páginas; o ㄲo 7, de maio de 1966, chega a ter 478 páginas, que são reduzidas a cerca de 260 a partir do no 13 . À época de seu lançamento, a revista terá como “diretor responsável” Ênio Silveira e como secretário Roland Corbusier.
} 
Em “Princípios e propósitos”, primeiro editorial, Ênio Silveira ${ }^{6}$ dirige-se aos leitores, convocando-os se posicionarem: "O povo brasileiro está agora diante de um grande e sério desafio: será capaz de, superando falhas e contradições, superar também as forças que se opõem ao desenvolvimento do País, numa linha democrática e independente?” (1:3-4)

Contenda, luta, provocação, a imagem do desafio pressupõe a existência de, no mínimo, dois atores: o desafiador e o desafiado. Pressupõe, portanto, antagonismos, enfrentamentos, contendores/cantadores em disputa, jogo de confianças e desconfianças. Assumindo a cena presente como um campo de forças opostas, um desafio que não permite recuos, o editorialista desdobra-se em desafiador / desafiado. Mas esta entidade totalizadora tão ambígua e tão sem forma -o povo brasileiro- não é o verdadeiro desafiado: a Revista conclama, de fato, aquela comunidade que se supõe guia e representante do "povo" e que pressupõe a resistência à ditadura como um valor compartilhado: "a tarefa, nesta quadra, caberá principalmente aos intelectuais, que acima de injunções ou posições partidárias, poderão estudar em seus mínimos pormenores a complexidade da vida brasileira” (1:3).

É a concepção da atividade intelectual como missão esclarecida e esclarecedora, educativa e desalienante, que delimita o "locus" desse desafio e empreende a cobrança ética e ideológica a este grupo bem específico, mas não menos informe: "os intelectuais" são os verdadeiros desafiados; a produção de conhecimento sobre a realidade brasileira, a arma da luta; a Revista, o veículo para divulgação desses estudos e pesquisas.

A Revista assume, desse modo, uma função pedagógica e esclarecedora em defesa da democracia, do socialismo, do desenvolvimento independente do país, da liberdade de criação artística e de imprensa; nela, ensinar e denunciar são funções mutuamente complementares. A Revista Civilização Brasileira propõe-se, portanto, como veículo do intelectual engajado, que ensina e denuncia, que assume o j'accuse!, que pratica o "delito de opinião" e vê no "golpe” a emulação necessária: "O golpe de abril,7 sendo mero episódio da crise crônica em que nos encontramos, certamente dificulta, mas por isso mesmo estimula, abre novas perspectivas e torna inadiável a tarefa que lhes cabe executar" (1:3).

Dentre os que aceitaram o desafio e afiaram suas armas, encontramos intelectuais com distintas trajetórias na cena política e cultural brasileira, ${ }^{8}$ os quais, a despeito das diferenças, deveriam estar inequivocamente identificados com e pelos princípios e propósitos da Revista:

\footnotetext{
${ }^{6}$ Sem assinatura na revista, o editorial é oficialmente creditado ao Conselho de Redação; Moacyr Félix, no entanto, atribui ao editor o crédito dos editoriais dos nos 1 e 13, ou seja, o de lançamento e o de comemoração dos dois anos da publicação. (Félix 383)

${ }^{7}$ A revista marca sua posição de resistência ao regime desde o ato de nomeá-lo: enquanto nos textos oficiais usam-se as denominações “Movimento de março de 1964”, "Revolução de março”, ou ainda "a redentora", tais termos aparecem, quando enunciados para o mesmo evento na Revista Civilização Brasileira, sempre repetidos entre aspas, em chave irônica, contrapondo-se como denominação "golpe militar", "golpe de abril”, ou ainda o predileto "o golpe de 1ํ de abril”, acentuando o sentido de fraude que a data comporta.

${ }^{8}$ Estou falando de intelectuais como Antonio Callado, Astrojildo Pereira, Barbosa Lima Sobrinho, Caio Prado Jr., Carlos Heitor Cony, Celso Furtado, Darcy Ribeiro, Fernando de Azevedo, Fernando Henrique Cardoso, Florestan Fernandes, Francisco Weffort, Francisco de Oliveira, Glauber Rocha,
} 
Não se deve inferir (...) que a Revista será ecumênica ao ponto de abranger todas as correntes de pensamento. É preciso deixar bem claro que não somente repudiará, como abertamente combaterá tudo aquilo que admitir como válida ou moralmente correta a presente estrutura sócio-econômica do Brasil ou entender como inevitável e até mesmo necessária a submissão dos interesses nacionais aos das grandes potências, sejam elas quais forem. (1:4)

Como se lê, a despeito de propostas de abertura para "diferentes caminhos" no exercício da resistência, demarcam-se com clareza os caminhos trilháveis: exige-se a defesa do socialismo e o conseqüente ataque ao sistema capitalista. A enfática retórica de luta deixa bem claro, ainda, o pressuposto nacionalista, ${ }^{9}$ ampliando o alvo a que resistir e demarcando a área do combate.

O editorial traça ainda o perfil que caracterizará a Revista, ou seja, define-lhe forma, abrangência e o campo de atuação:

(...) fugirá deliberadamente ao gratuito, porque acredita indispensável um alto índice de objetividade aos trabalhos que acolher em suas páginas. Não se ocupará do fait divers, mas daquilo que tenha conteúdo e sentido. (...) No terreno dos estudos políticos, sociológicos, econômicos e culturais, (...) buscará sempre amplitude de visão sem perder profundidade de análise. (1:3-4)

Esse perfil se delineia desde o primeiro número, dedicado a traçar "balanços da situação” em todas as seções, ${ }^{10}$ através de um modo de atuar em que "amplitude de visão e profundidade de análise” parecem ser identificadas com o tipo de estratégia textual predominante: produz-se um balanço histórico como subsídio (causa) para a compreensão do presente (efeito) e os prognósticos de futuro bem como a proposta de ações neste mesmo presente com vistas a um outro futuro. Nesses textos analíticos, predomina a linguagem acadêmica, especializada, em que não faltam dados de pesquisa, tabelas,

Gustavo Dahl, Jânio de Freitas, Jean-Claude Bernadet, José Arthur Giannotti, Leandro Konder, Osny Duarte Ferreira, Otto Maria Carpeaux, Paul Singer, Rogério Duarte, Roberto Schwarz, Sebastião Uchoa Leite, além dos integrantes do Conselho de Redação, composto por Alex Viany, Álvaro Lins, Antonio Houaiss, Cid Silveira, Dias Gomes, Edison Carneiro, Ferreira Gullar, Haiti Moussatché, M. Cavalcanti Proença, Moacyr Félix, Moacyr Werneck de Castro, Nelson Lins e Barros, Nelson Werneck Sodré, Octavio Ianni, Paulo Francis, Oswaldo Gusmão. A explicitação dos nomes que integram o Conselho desaparece da revista a partir do n.5/6, de março de 1966.

${ }^{9}$ Essa “militância em prol do Brasil” marcará o discurso de algumas gerações, legitimando posturas igualmente autoritárias à direita e à esquerda e nos vários campos culturais, como o debate gerado, ainda nos anos 60, em torno da "pureza" da música popular brasileira diante das guitarras elétricas incorporadas pelo tropicalismo, mas não pela Revista Civilização Brasileira, ou, na década seguinte, as discussões sobre as "patrulhas ideológicas".

${ }^{10} \mathrm{O}$ nº-1 apresenta-se dividido nas seguintes seções: Política Nacional, Política Internacional, Economia, Literatura, Cinema, Teatro, Artes Plásticas, Música, Documentário. Tal estrutura se mantém, com alguns acréscimos ou supressões até o no 11/12, mantendo-se daí em diante apenas o rol dos artigos sem divisão em rubricas. Seções acrescidas em alguns números: Problemas Culturais e Filosóficos, Problemas Sociais e Políticos, Ciência e Tecnologia, Cultura Popular, Direito. 
discussões, que constroem o tom, a aura de seriedade e objetividade científica, de racionalidade, de verdade, em suma. Assim são tratadas tanto as questões políticas, econômicas e sociais, ${ }^{11}$ como aquelas relacionadas às artes, à estética, à literatura, enfim, ao que se considera "cultura” no âmbito da Revista.

Além dos ensaios e análises críticas, a Revista publica ainda textos de denúncia, de resistência explícita. Em linguagem ora irônica, ora panfletária, sempre muito enfática, ataca o regime militar denunciando incessantemente suas arbitrariedades, ${ }^{12} \mathrm{com}$ destaque para fatos envolvendo os principais colaboradores da Revista, muitos dos quais, a exemplo do editor, eram membros do então proscrito Partido Comunista Brasileiro e alvos diletos do Regime. Assim, na seção "Documentário” e, algumas vezes, na esporádica seção "Direito", são publicados na íntegra os atos institucionais (AI) e complementares (AC), as peças de acusação e defesa em IPMs, ${ }^{13}$ habeas corpus concedidos, matérias dos jornais em defesa de intelectuais presos, relatos do vivido nestas situações, dossiês temáticos elaborados pelo Conselho de Redação, ${ }^{14}$ histórico e repercussão de atos de censura na área

\footnotetext{
${ }^{11}$ Discutem-se, por exemplo, inflação, dívida externa (e as pressões do FMI), pobreza, desigualdade, reivindicações trabalhistas, saúde, alfabetização, ciência e tecnologia, universidades (incluindo-se a denúncia do acordo MEC-USAID), industrialização, a questão agrária (com análises do "estatuto da terra” e da reforma agrária), questões raciais e de gênero (sim, a revista já publica textos sobre a posição da mulher na sociedade), e por mais que pareça estarmos nos referindo a temas do fim do século xx e início do século xxi, eles já estavam lá, na segunda metade da década de 60, na Revista Civilização Brasileira.

${ }^{12}$ Exemplos desse discurso de oposição explícita ao governo militar, muitas vezes militante e panfletário, são as duas irônicas e duras cartas abertas que Ênio Silveira dirige ao Marechal Castelo Branco, inspirado nas cartas de Norman Mailer a John Kennedy. Na primeira delas, "Sobre o delito de opinião" (3: 3-11), o autor explicita sua defesa das liberdades individuais, seu nacionalismo, sua oposição ao regime imposto pelos militares, sua luta histórica, suas recentes prisões por "delito de opinião", defendendo as posições que o tornaram "subversivo" aos olhos do governo do Marechal, não sem antes ironizar: "O Senhor poderia argumentar que eu não sou Norman Mailer; mas o Senhor também não é John Fitzgerald Kennedy.” (4) E para conclui, reitera: “O ‘delito de opinião’, Senhor Marechal, é o crime que devemos todos praticar diariamente, sejam quais forem os riscos. Se deixarmos de ser 'criminosos', nesse campo, seremos inocentes... e carneiros.” (p.11) Não é preciso lembrar que a censura prévia ainda não estava instalada no país.

${ }^{13}$ A título de exemplo, vale citar o dossiê-documentário "O 'IPM DA FEIJOADA': a prisão de Ênio Silveira”, cuja irônica apresentação transcrevo aqui: “Tendo oferecido uma feijoada ao governador Miguel Arraes de Alencar e a outros amigos, o editor Ênio Silveira foi acusado de lhe haver dado guarida em sua residência, antes que aquele político se asilasse na embaixada da Argélia. A acusação, infundada, lhe valeu prisão de 9 dias, determinada pelo Coronel-Intendente Gerson de Pina. O objetivo verdadeiro dessa violência, no entanto, era o de intimidar o editor, a fim de que ele não continuasse a exercer sua atividade como o vinha fazendo. Esse novo atentado à liberdade de opinião causou generalizada repulsa em todo o país; reunimos nesse documentário alguns artigos e editoriais da imprensa, o Manifesto de 600 intelectuais brasileiros e o texto completo do habeascorpus impetrado ao STM pelo advogado do editor, Professor Heleno Cláudio Fragoso. Entre os editoriais figura, como exceção lastimável, pelo que tem de inoportuno e tendencioso, o do Jornal do Brasil, de 28.5.1965.” (3: 341). Sobre este caso, ver ainda Gaspari (230-232).

${ }^{14}$ Também como exemplo cito "Terrorismo cultural" (1:239-297), relato "cujo título tomamos emprestado” (239) de artigo de Alceu Amoroso Lima. Nele a Revista faz um balanço / denúncia da
} 
cultural, enfim, todo um material que, denunciando as forças repressivas, cumpria a função de informar o leitor a respeito do "terrorismo cultural” em curso, construindo, assim, um importante histórico do período 1964-1968.

Apesar da perspectiva fortemente nacionalista, a Revista não exclui questões nem colaboradores internacionais, como também se afirma, pela negação, nos “princípios e propósitos”. ${ }^{15}$ Mas articular uma relação ao mesmo tempo cosmopolita e modernizadora a um projeto nacionalista não deixa de ser mais um desafio que a Revista procura enfrentar através da coerência político-ideológica: no contexto da guerra-fria, era preciso condenar as ações e o estilo de vida norte-americanos (especialmente a guerra do Vietnã, a invasão de São Domingos, a forma de atuar/intervir nas questões latino-americanas, a questão racial e dos direitos humanos) e valorizar, claro, a revolução cubana. É importante ressaltar, todavia, que as opções partidárias e ideológicas não impedem uma tomada de posição francamente contrária à invasão da Tchecoslováquia pela URSS; ${ }^{16}$ do mesmo modo, o no 19/20 (maio-agosto de 1968) traz uma série de textos que analisam, de distintos ângulos e posições, os eventos de maio de 1968, ou a “rebelião dos estudantes”, como se lê na capa.

Essa “abertura” às questões e colaborações estrangeiras trouxe para a Revista e seus leitores não apenas nomes internacionais de prestígio, ${ }^{17}$ mas autores e textos importantes que nela circularam no Brasil pela primeira vez, como Walter Benjamin e Theodor W. Adorno, além de outros pensadores mais freqüentemente traduzidos e publicados. Revelam-se assim preferências teóricas, como é o caso de Georg Lukács (o mais freqüente), Lucien Goldmann, Berthold Brecht, Roger Garaudy, Antonio Gramsci, Herbert Marcuse, Jean-Paul Sartre, além dos menos freqüentes Ernst Fischer, André Gorz, Eric Hobsbawm, Karel Kosik, Perry Anderson e Louis Althusser, apenas para dar algum

situação dos intelectuais e da cultura no Brasil, tomando como uma das considerações preliminares que "o golpe de abril não foi manso; muito ao contrário, foi sangrento, terrorista, brutal” (1:240), para, denunciando as arbitrariedades e violências cometidas desde abril de 1964, com farta exemplificação do ataque a intelectuais, universidades, religiosos, artistas, cientistas, estudantes e escritores, concluir: "o que existe, hoje, neste país, é um imenso, gigantesco e ignominioso IPM contra a cultura.” (1:297). À página 278, denuncia-se que Gilberto Freyre “dedodurara mestres” da Universidade do Recife, segundo o ex-reitor da instituição.

15 “A Revista Civilização Brasileira não ignorará as experiências estrangeiras, naquilo que possam conter de colaboração útil ao processo nacional. (...) Não será tolhida por um nacionalismo sentimentalóide e estreito, mas por certo não cairá nos esquemas geopolíticos, nos planejamentos estratégicos continentais que o State Department e o Pentágono idealizam e que certas figuras da política nacional executam.” (1:3-4)

${ }^{16}$ Como se sabe, o Partido Comunista Brasileiro era alinhado ao Partido Comunista Soviético da era Khrushchev (ver Brasil: nunca mais 91). A Revista dedicou seu Caderno Especial 3 ao tema, criticando veementemente as ações soviéticas através de textos de origens distintas, nacionais e internacionais, que analisam a situação e defendem a liberdade para o país invadido.

${ }^{17}$ Por exemplo, registre-se a publicação de um manifesto pacifista do ganhador de dois prêmios Nobel, Linus Pauling, bem como a da carta a ele dirigida por Ho Chi Minh, na qual o presidente do Vietnã do Norte agradece cópia do documento em que oito ganhadores do Nobel da Paz, liderados por Pauling, apelam aos governos e partes interessadas na guerra para que dêem início imediato à negociação da paz. 
exemplo da plêiade que circula na Revista e, muitas vezes, no catálogo da editora de Ênio Silveira, dando ao leitor brasileiro a oportunidade de acompanhar o pensamento marxista internacional (e nacional) inclusive em seus próprios antagonismos. Aliás, os debates entre distintas posições dentro do marxismo são saudavelmente freqüentes nas páginas da Revista Civilização Brasileira e adquirem maior visibilidade nas seções dedicadas à cultura, especialmente no plano teórico e estético. ${ }^{18}$

Dentre as seções culturais, a que contém o maior número de matérias é a de literatura: antecede as demais na ordem de apresentação, conta com variedade de colaboradores e colaborações (comentários, críticas, ensaios, poemas, traduções, entrevistas) e é a única das rubricas na área cultural presente em todos os números da Revista, sem exceções, marcando a tradicional predominância do literário na vida cultural e intelectual do país e, sintomaticamente, na própria direção da Revista.${ }^{19}$ Mas é curioso, e também sintomático, que no panorama cultural traçado pela Revista Civilização Brasileira o teatro e o cinema sejam as áreas consideradas de grande desenvolvimento na cultura brasileira, seguidas pelas artes plásticas, concentrando-se nas seções respectivas os pontos fortes da discussão estética e cultural, inclusive pelo espaço de debate que nelas se abre. Tais discussões envolvem profundamente não apenas a problemática do realismo x anti-realismo, mas também e especialmente as questões da indústria cultural, do investimento estatal, da nacionalização, da formação de público, da mercadoria e do estatuto da obra de arte, além da função política articulada ou em contraposição à problemática estética, que trazem à tona e antecipam boa parte dos debates que se travarão nas décadas seguintes.

A seção "Cinema", sob a responsabilidade de Alex Vianny, inaugura-se pondo em cena sua grande estrela, o Cinema Novo, ${ }^{20}$ protagonista das discussões sobre as

\footnotetext{
${ }^{18}$ Os profundos antagonismos na esquerda brasileira, acentuados após 1964, que se sucedem na análise da "derrota" sofrida e no debate sobre as táticas de ação e resistência a serem adotadas produzem os conhecidos "rachas" que dividiam os partidos e os militantes de esquerda no Brasil, especialmente quanto à opção pela "luta armada no campo" ou pela "guerrilha urbana", nenhuma delas aceita pelo Partido Comunista Brasileiro. Acrescentado-se ainda os alinhamentos aos distintos partidos de esquerda no plano internacional, tudo isso, que desmonta a propalada "coesão das esquerdas" diante do inimigo comum, é uma luta de bastidores, clandestina, sem visibilidade na Revista Civilização Brasileira.

${ }^{19}$ À época de seu lançamento, a revista terá como “diretor responsável” Ênio Silveira e como secretário Roland Corbusier. A partir do no 5/6, de março de 1966, M. Cavalcanti Proença, crítico, "homem de letras", assume a direção, tendo o poeta Moacyr Félix como secretário; com o falecimento de Cavalcanti Proença, Moacyr Félix assume a direção a partir do no 9/10, tendo Dias Gomes como secretário, configuração que se mantém até o oํ 21/22 (setembro-dezembro 1968), último a ser publicado. A seção "literatura" é coordenada por Nelson Werneck Sodré, militar reformado, historiador (inclusive da literatura), também um "homem de letras”, essa espécie em extinção, assim como vários outros membros do Conselho da Revista.

${ }^{20}$ A apresentação de Alex Vianny para "Cinema Novo: ambições e perspectivas” fala por si: "Para inaugurar essa seção, achei oportuno gravar uma conversa com Nelson Pereira dos Santos e Glauber Rocha, autores, respectivamente, de Vidas Secas e Deus e o Diabo na Terra do Sol, que são, em minha opinião -e certamente na opinião da maioria dos críticos- , os dois melhores filmes até agora produzidos pelo movimento a que chamamos Cinema Novo. Além disso (...), Nelson Pereira dos Santos é praticamente o mentor, o papa ou papai do movimento. Por isso, propus a eles todo um
} 
possibilidades reais de um cinema brasileiro, construtor de uma cultura nacional brasileira, no embate com o cinema industrial estrangeiro. Discutem-se ainda a oposição entre indústria e produção independente, o dilema da obtenção de público sem “fazer concessões”, o impacto da televisão, a crítica, o cinema de autor, o filme engajado em oposição ao filme “burguês”, enfim, questões estéticas, ideológicas, políticas e econômicas ${ }^{21}$ que continuam a repercutir nas décadas seguintes.

Mesmo que em outra escala, tais questões são igualmente discutidas a propósito da atividade teatral, em que, ao mesmo tempo, detecta-se forte crise e grande vigor: crise de público, das companhias de repertório, vigor do teatro "de resistência” e dos encenadores e dramaturgos "progressistas", cuja forte politização é potencializada pelo arbítrio / ignorância dos censores, ${ }^{22}$ que chegaram a proibir peças de Tenessee Williams, Górki, Feydeau, Brecht e Sófocles. ${ }^{23}$ A importância que a Revista dá ao teatro se materializa na produção de um antológico “Caderno Especial 2: Teatro e Realidade Brasileira”, em cuja foto de capa Glauce Rocha e Paulo Autran dividem as escadarias do Teatro Municipal do Rio de Janeiro com outros atores e autores em greve que ostentam cartazes com dizeres “contra a censura pela cultura”. Organizado por Dias Gomes, este “caderno” sintetiza e complementa, de algum modo, a seção “Teatro" 24 da Revista, em que as discussões, com prós e contras, se travam em torno do realismo e do engajamento, das oposições ao esteticismo, do confronto de linhagens (o nacional-popular dos Centro Populares de Cultura ou o já tradicional cosmopolitismo do Teatro Brasileiro de Comédia?), das formas de produção teatral, da formação de platéia (povo? massa? elite?), dos embates com o teatro “digestivo" da Broadway e com a televisão, discussões sempre pautadas pela defesa de um teatro nacional. Tudo isso dará visibilidade tanto às diferentes posições no seio da

elenco de perguntas, no sentido de obter seus depoimentos pessoais sobre as origens e os propósitos desse Cinema Novo. O que se segue é um resumo da conversa, que transcrevi e coordenei, procurando conservar o máximo possível da espontaneidade da gravação” (1:185).

${ }^{21}$ Nesta seção, colaboram críticos e cineastas ligados ao Cinema Novo como Gustavo Dahl, um dos mais freqüentes, além de Jean-Claude Bernadet, Octavio Ianni e Roberto Schwarz que, em se tratando de cinema, poderíamos denominá-lo "bissexto". A seção publica ainda textos programáticos de cineastas como Fritz Lang e Pasolini; destaca-se também o manifesto hoje antológico "Uma estética da fome”, de Glauber Rocha. A partir do $\mathrm{n}^{\mathbf{0}} \mathbf{1 5}$, e com exceção do $\mathrm{n}^{\mathrm{0}} \mathbf{1 8}$, desaparecem da Revista os textos sobre cinema.

${ }^{22}$ O caso da proibição da peça $O$ berço do herói, de Dias Gomes, no dia da estréia e por ordem do governador Carlos Lacerda, é relatado detalhadamente pelo próprio autor na Revista Civilização Brasileira (4:257-268). Ganham destaque, ainda, as montagens do Arena, do Oficina, dos grupos Opinião e Decisão.

${ }^{23}$ A Revista transcreve, do jornal Última Hora (10/05/65) , diálogos entre atrizes e agentes da repressão que seriam hilariantes se não fossem trágicos: em dois interrogatórios distintos porém iguais, os agentes perguntaram às atrizes Isolda Cresta e Glauce Rocha se esse tal de Sófocles, autor de Electra (então em cartaz pelo grupo Decisão), era subversivo ou soviético.... (Caderno Especial 2: 254)

${ }^{24}$ Além de Dias Gomes, a seção tem como colaboradores freqüentes Paulo Francis e Luiz Carlos Maciel, incluindo, dentre outros, Anatol Rosenfeld, Yan Michalski, Fernando Peixoto e traduções de ensaios de Brecht e de Susan Sontag. 
classe teatral e da crítica marxista como à crise anunciada e vivida plenamente pelo teatro brasileiro nas décadas seguintes.

Embora menos efervescente que a seção “Teatro”, “Artes Plásticas” se destaca pela forte colaboração crítica de Ferreira Gullar, analisando e discutindo, dentre outros aspectos, as tensões entre o figurativo e a abstração, a vanguarda e a internacionalização da arte, debate permeado pelas implicações, na obra de arte, da tensão entre o fenômeno estético, que implica o papel do crítico de arte, e o conceito de mercadoria, que implica o papel dos marchands. O poeta exercita a crítica de obras concretas, tratando ora da produção de artistas individuais, ora de exposições coletivas, faz entrevistas com diversos artistas e produz o que talvez seja a mais importante reflexão estética da Revista, discutindo a arte em tempos regidos pela lógica da mercadoria e refletindo criticamente sobre os meios de comunicação, a cultura de massas e seu papel na sociedade, como o faz na série "Problemas estéticos na sociedade de massas". ${ }^{25}$

Se a Revista propicia boas discussões ao tratar do cinema, do teatro e das artes plásticas, o mesmo não se pode dizer das seções “música” e "literatura”, fragilizadas pelo reduzido espaço de controvérsias e pela rigidez ideológica que acabaria por levá-las tanto à impossibilidade de perceber o que efetivamente acontecia de importante nestas áreas como a grandes equívocos críticos. Apesar da forte movimentação na área musical durante o período de publicação da Revista ${ }^{26}$ a seção "Música" ocupa um espaço relativamente pequeno, chegando a praticamente desaparecer da Revista após o no 9/10. ${ }^{27}$ Dedicando-se prioritariamente a recusar as influências estrangeiras, especialmente a norte-americana, a cobrar a valorização do samba popular em oposição à bossa-nova (condenada pela influência do jazz , e por seus "vínculos burgueses" de "samba zona sul”), e valorizando compositores e intérpretes pelo grau de preocupação social revelado em suas letras, a seção "Música" revela-se conservadora e até saudosista, esteticamente, apesar de “progressista” politicamente. Em 1966, no entanto, a seção promove um debate (7: 375385) que de algum modo a redime: reunindo os críticos Flávio Macedo Soares e Nelson Lins e Barros, o cineasta Gustavo Dahl, a cantora Nara Leão, o poeta e crítico Ferreira

\footnotetext{
${ }^{25}$ Dividido em 3 partes, o ensaio de Ferreira Gullar saiu nos números 5/6, 7 e 8 da Revista Civilização Brasileira , e posteriormente em livro. Nestes ensaios, o crítico e poeta toma como um dos suportes teóricos de sua argumentação o ensaio de Benjamin sobre a obra de arte a partir de uma edição francesa (não citada no livro), e menciona, via Ernst Fischer, o ensaio sobre Baudelaire, o que nos permite inferir que Gullar, como membro do conselho de Redação, tenha sido um dos responsáveis pela pioneira inclusão de Benjamin no número 19/20 da Revista. Sobre os ensaios de Gullar e a importância da Revista Civilização Brasileira ver Carlos Guilherme Mota (1977) e, ainda, sobre o pioneirismo de Gullar e da Revista Civilização Brasileira na discussão sobre sociedade e a cultura de massas, ver Renato Ortiz (1988).

${ }^{26}$ É o período de realização dos grandes festivais de MPB, de espetáculos musicais importantes, do surgimento de novos compositores e do Tropicalismo, e, inclusive, das tensões e conflitos entre os músicos ligados à MPB e aqueles ligados à "música jovem” influenciada pelo "rock-and-roll”. ${ }^{27} \mathrm{O}$ falecimento de Nelson Lins e Barros, responsável pela seção e membro do conselho, pode ter sido decisivo para a ausência da seção música. Sérgio Cabral escreve o necrológio para Nélson Lins e Barros (9/10: 265-268). A seção "Música”, tratando quase exclusivamente da música popular brasileira, contou ainda com as colaborações de José Ramos Tinhorão, João Antonio, Airton Lima Barbosa, Flávio de Macedo Soares Regis e Sidney Miller.
} 
Gullar, o poeta e compositor Capinam e o ainda pouco conhecido Caetano Veloso, ${ }^{28}$ as diferenças podem vir à tona e trazer, mesmo que minimamente, algumas dissonâncias na dicotomia de valores hegemônica no periódico. Nesse debate, o "novo baiano" chama atenção para um necessário redimensionamento do conceito de tradição nacional e popular, reivindicando a retomada da "linha evolutiva" da música brasileira não como saudosismo, mas como material a ser recriado pela informação da "modernidade musical”, apontando para as futuras práticas do tropicalismo ${ }^{29}$ que a Revista não foi capaz de ouvir, nem de assimilar.

Dos mesmos males -conservadorismo estético e dogmatismo político- padece a seção Literatura nas fartas páginas ocupadas com ensaios críticos, poemas, entrevistas, traduções e, a partir do nํㅡㄹ 2, com uma rubrica fixa, assinada por Nélson Werneck Sodré. ${ }^{30}$

Os balanços da prosa e da poesia que podemos ler no primeiro número da Revista traçam com razoável precisão a perspectiva crítica da seção Literatura, que se manterá, com algumas vozes dissonantes, ao longo dos 22 números publicados. Assim, em "Poesia Brasileira em 1964”, M. Cavalcanti Proença assume como pressuposto e ponto de partida que o engajamento é “condição da própria condição artística, e corresponde ao estar em situação com sua época, bem diferente, segundo Sartre, do populismo” (1:161).

Embora evocando Sartre como antídoto a possíveis acusações de populismo, que inevitavelmente evocam a década de $40,{ }^{31}$ nosso crítico não escapa aos critérios de valor pautados pela ortodoxia ideológica que o levam a destacar o poeta Cassiano Ricardo em detrimento de Bandeira e Drummond como o grande modernista desta tríade, Geir Campos em relação a Ledo Ivo e, dentre os mais novos, todas as loas vão para Moacyr Felix. Como anunciado, as avaliações decorrem do grau de engajamento, sem desconsiderar, ressalva o crítico, a qualidade formal ou o apuro técnico atingidos pelo poeta. Sabemos todos o tratamento que a crítica marxista "tradicional” dá à poesia não comunicativa da modernidade, suas críticas ao rigor formal sem a correspondente ênfase nas relações entre o eu e o mundo, ou entre poesia e sociedade. E não será de outro modo na Revista Civilização Brasileira, conforme o balanço da poesia brasileira feito por Cavalcanti Proença já prenuncia. A Revista irá criticar, por exemplo, João Cabral de Melo Neto por sua crescente esterilidade; irá ignorar os poetas concretos, salvo pela breve referência ao

\footnotetext{
${ }^{28}$ Apresentação do debate: "Em virtude da crise atual da música popular brasileira, a Revista Civilização Brasileira reuniu músicos, compositores, intelectuais e estudiosos de música popular para um debate sobre os caminhos da música popular brasileira, que foi organizado e coordenado por Airton Lima Barbosa, do Quinteto Villa-Lobos.” (7:375) (grifo meu)

${ }^{29}$ Caetano ganha, com essa participação, o reconhecimento dos grupos intelectuais que se consideravam de vanguarda, como os poetas concretos paulistas, especialmente Augusto de Campos, desafetos públicos de Ferreira Gullar. Sobre a participação de Caetano neste debate ver Celso Favaretto e Augusto de Campos.

${ }^{30}$ Membro do Conselho de Redação e responsável pela seção "Literatura”; a rubrica surge com o título "Notas de crítica" no segundo número da Revista e passa a chamar-se, a partir do ㄲo 3, "O Momento Literário", coluna que se publica até o último número (22), com exceção apenas dos nํㅗ $11 / 12$ e 13.

${ }^{31}$ Ver, a propósito, o importante estudo de Raúl Antelo (1985) sobre três revistas brasileiras em suas relações com o Estado Novo e com o Partido Comunista.
} 
resgate de Sousândrade; irá igualmente ignorar Drummond, Murilo Mendes, Cecília Meireles e, por ocasião dos 80 anos do poeta Manuel Bandeira, apenas fará o registro do lançamento de Estrela da vida inteira, antecedido de um irônico "para os apreciadores de Manuel Bandeira” (SODRÉ, 8: 149), como um acontecimento, digamos, “menor” diante do lançamento de A luta corporal”, de Ferreira Gullar.

A política de inclusões e exclusões na seção Literatura parece ser regida por Nélson Werneck Sodré: "homem de letras" em velho estilo, o agora "progressista" faz de seu "O momento literário” um espaço de denúncia política, de informações editoriais, de juízos de valor, tudo em tom de conversa com o leitor, esse misto de aprendiz e cúmplice. Afirma veementemente o que nega na prática, isto é, a isenção de julgamento estético e o não apadrinhamento dos amigos. Seu conceito de "literário" comporta ficção (conto e romance), ensaio (sobre quaisquer assuntos), traduções, ou seja, movimento editorial em sentido amplo e, claro, as revistas de cultura. Curiosamente, o crítico não esconde o desejo do Conselho de Redação para que sua seção reduza a mera informação em benefício do ensaísmo crítico, da análise das obras, mais condizente com o tom geral do periódico. É verdade que Sodré, embora resista, atende, ao menos parcialmente, a tais reivindicações; mas não é menos verdadeiro que o mau juízo que faz da crítica que lhe é contemporânea vai além da apreciação politicamente orientada, e ressuscita o debate entre o "homem de letras” e o crítico universitário, transformado em crítica nova X crítica velha. Diz Sodré:

São [Antonio Candido e Rolando Morel Pinto] típicos representantes da crítica velha. [...] Nos críticos mais pretensiosos, a estria destacada é a sociológica, lidando com elementos fornecidos pela sociologia empírica norte-americana. Por trás dessa parafernália supostamente profunda está a cátedra universitária, que reveste de autoridade dogmática o que dela provém, como sagrado. [...] Só agora, com a nova crítica - e não se mistura, pelo título, a autêntica com a contrafação - essa escala de valores começa a ser revista. [...] velhos conceitos e velhos processos estão desmoralizados, e continuam a vigorar, entretanto, nas cátedras universitárias, nas revistas especializadas, nos rodapés de jornais, enquanto novos conceitos e processos começam a surgir, mas não se generalizaram ainda. Como a crise do ensino universitário força a juventude, hoje, a procurar o caminho do autodidatismo, a crítica nova começa a firmar-se em trabalhos como o de Carlos Nelson Coutinho. É, realmente, [...] aquilo que se firmará sem contestação quando for removido o entulho da velha crítica, ainda obstruindo algumas passagens, e particularmente as universitárias. (17:195-196)

Apesar do equívoco dessa avaliação, que o tempo já demonstrou, é Carlos Nélson Coutinho, tradutor de Lucien Goldman e Lukács, o crítico predileto de Werneck, ${ }^{32}$ o representante da "nova crítica” em oposição à “velha”, a “crítica universitária”. Uma "nova crítica” marcada pelo sectarismo e pela ortodoxia, centrada em Goldmann e Lukács,

\footnotetext{
${ }^{32}$ Dentre os críticos brasileiros em atividade e além de Carlos Nelson Coutinho, Sodré elege / elogia Roberto Schwarz como "um dos melhores valores, realmente, da atual crítica brasileira" (4:178); faz ressalvas a José Guilherme Merquior - "uma das grandes revelações da crítica brasileira atual” (4:177)- cobrando-lhe uma posição política: "terá de escolher [...] o Brasil não dispõe de muitos valores de seu nível para aceitar que um escritor desse porte acabe conformando-se em ser simplesmente o que aceitou ser, por exemplo, o Sr. Gilberto Freyre” (4:177-178).
} 
apoiada em Althusser, que, em nome do realismo e do racionalismo, recusa Clarice Lispector e Guimarães Rosa. Como observa Sodré, não se confunda esta "nova crítica" com "new criticism”, nem com a crítica estruturalista então emergente, nem com a crítica de base sociológica e de esquerda praticada por Antonio Candido, nem com o estruturalismo, que começa a ser adotado como crítica universitária no Brasil e imediatamente criticado pela esquerda brasileira. ${ }^{33}$ Mas, justiça seja feita, Werneck Sodré acolhe na seção que dirige vozes dissonantes, que acabam por relativizar essa tão problemática via de mão única: servem como exemplo os ensaios de Fernando G. Reis em defesa de Clarice Lispector e o de Fritz Teixeira Salles, que faz sérios reparos a Carlos Nelson Coutinho em defesa da pesquisa estética, chegando a ver no então jovem crítico resquícios de jdanovismo. Boas falas, sem dúvida.

Neste embate crítico com seu próprio tempo, a Revista Civilização Brasileira compartilha o espaço cultural com muitas outras revistas. De um modo geral, Werneck Sodré sempre dedica algumas linhas de sua coluna a falar -geralmente mal- das revistas em circulação. E é a partir desse campo que o crítico atribui sentido à própria Revista:

Temos poucas revistas de cultura, e as que temos não se distinguem pelo alto nível. Há motivos para isso, evidentemente. Não é aqui o momento e o lugar de expô-los e discutilos. O aparecimento desta Revista, aliás, pretende ser uma resposta à situação. (2:166)

Evidentemente, a lógica de exclusões e inclusões opera aqui também, e faz com que sejam saudados os lançamentos das revistas Teoria e Prática e Paz e Terra, ambas situadas no mesmo campo da resistência de esquerda ao governo militar. ${ }^{34}$ Também nesse campo, Sodré faz elogios à longeva revista Leitura, publicada desde 1942 (apesar da interrupção entre 1948 e 1954), e que compartilha vários colaboradores com a Civilização Brasileira, como Otto Maria Carpeaux e Alex Viany, embora não compartilhe da mesma ortodoxia, especialmente no campo literário. ${ }^{35}$ Será preciso dizer que todas sucumbem diante do AI5 ?

Muitas outras revistas são criticadas, desde, e pour cause, as institucionais, como a Revista do IEB, da USP, e a Revista do Livro, do INL, ou as estritamente literárias, como Praxis, revista do movimento homônimo, liderado por Mario Chamie, que procura

\footnotetext{
${ }^{33}$ A mais dura crítica ao estruturalismo nas páginas da Revista é feita por Otto Maria Carpeaux no ensaio "Estruturalismo, o ópio dos literatos" (8: 245-250), completado por uma charge de Jaguar, "Estruturalismo", em que vemos uma jovem perguntar a um homem barbudo, careca e de óculos: “O Sr. faz poemas a régua ou a mão livre?” (8:250)

${ }^{34}$ A primeira surgiu em São Paulo, em 1967, e teve apenas 4 números publicados; era dirigida por Sérgio Ferro e tinha entre seus idealizadores e colaboradores Roberto Schwarz e Rui Fausto, além de Jean-Claude Bernadet; mesmo assim, não escapa à acidez de Sodré: "a matéria é bastante heterogênea, o que revela, de um lado, tolerância com valores e pretensos valores, um pouco de cerimônia, e particularmente com titulares universitários [...].” (18:135) A revista Paz e Terra, assim como a editora de mesmo nome, também foi idealizada por Ênio Silveira e dirigida por Moacyr Felix como o exercício da resistência no campo das religiões e numa perspectiva ecumênica. Ver relato de Waldo Cesar sobre a criação de ambas -editora e revista ( Felix 413-417).

${ }^{35}$ apenas como exemplo, o número 83/84, de junho-julho de 1964, homenageia Cecília Meireles, "poeta maior", com direito a foto e chamada na capa.
} 
associar o experimentalismo estético de vanguarda à participação política, até a conservadora Convivium, que merece de Sodré um comentário no mínimo mordaz:

...um sr. José Francisco Coelho pergunta por que os intelectuais brasileiros são quase todos de esquerda. Isso o perturba. Tenta explicar, e escreve que isso acontece porque os intelectuais, em países como o nosso têm 'um papel importante no movimento de libertação das classes oprimidas e em sua integração na comunidade em condições humanas.' Parece uma razão. Ou não parece? ( 7: 166)

Não cabe aqui citar a grande quantidade de pequenas revistas mencionadas por Werneck Sodré, que incluem muitos periódicos estudantis, de grêmios universitários e diretórios acadêmicos, o que é sintoma claro da forte atuação experimentada pelo movimento estudantil entre 1964 e 1968, ou algumas outras revistas literárias “engajadas” politicamente como Serial, publicada na Bahia pelo poeta Antonio Brasileiro. Isto é matéria para outra pesquisa. Quero registrar aqui apenas duas exclusões bastante significativas: Sodré seque menciona as revistas Invenção e Tempo Brasileiro.

A primeira, do grupo paulista de poetas concretos, talvez uma das últimas "revistas literárias” em sentido estrito, ${ }^{36}$ fica fora de Civilização Brasileira recusada por um sectarismo ideológico que não aceita a militância formalista e estetizante, o elogio a Ezra Pound, o desejo da internacionalização. Talvez se possa dizer que Invenção tenha sido o veículo da última formação literária do século xx no Brasil. ${ }^{37} \mathrm{E}$, neste sentido, a vida curta de Invenção, nos anos 60, pode ser pensada como sintoma das grandes mudanças em curso.

Já a Tempo Brasileiro, criada dois anos antes do golpe militar, atravessou incólume todo o período da ditadura, com apenas uma leve interrupção no ano de 1964,e continuou a ser publicada até fins dos anos 90. Dirigida por Eduardo Portela, seu perfil acadêmico, que prioriza a publicação de ensaios críticos e analíticos, e sua “cara de livro” aproximamna da revista de Ênio Silveira. Mas as opções políticas, ideológicas, e, conseqüentemente, teóricas e críticas afastam-nas irreversivelmente. Apenas Tempo Brasileiro sobreviveu.

\section{Contra fato há ARgumento}

O lançamento, em 1969, com grande sucesso de público, de O Pasquim, faz daquele início de década ${ }^{38}$ um momento cultural ambíguo, controvertido, tenso e distenso ao

\footnotetext{
${ }^{36}$ isto é, aquela revista entendida como publicação periódica, geralmente efêmera, de pequena tiragem, dedicada a expressar ou a defender o ideário crítico e estético de um determinado grupo. ${ }^{37}$ A palavra formação é aqui empregada na acepção que lhe dá Raymond Williams (1992). Também no campo da poesia de experimentação, surge e desaparece, entre 1962 e 1966, a revista Práxis, concorrente menor de Invenção, e a mineira Tendência, dirigida por Afonso Ávila, que mantém com Invenção forte diálogo, podendo ser pensada no âmbito do concretismo. Epígonos de Invenção, outras revistas literárias de mesma linhagem surgem a partir de meados dos anos 70: PoesiaemG, Código, Muda, Qorpo Estranho, além de Através e Polímica. Hoje devidamente extintas, podem ser lidas como "resíduos culturais" ao ressurgirem num momento em que as vanguardas, inclusive essa tardia e auto-denominada "vanguarda brasileira", já completaram seu ciclo histórico: sinais de esgotamento de qualquer idéia de vanguarda.

${ }^{38}$ Pode-se dizer que a década de 70 começou, no Brasil, em 13 de dezembro de 1968, com a decretação do AI-5, e terminou em 1979 com a lei da anistia. O Ato Institucional nํㄷ fechou o
} 
mesmo tempo, em que sai de cena o discurso explícito da resistência para dar lugar ao subentendido, ao alegórico, ao condicional, ao alusivo, enfim, a outras táticas discursivas. ${ }^{39}$

Percebido pela intelectualidade como um momento de forte vazio cultural, ${ }^{40}$ aquele início de década, ao mesmo tempo tão cheio de temores e das últimas utopias revolucionárias, era de fato repleto de produtos culturais de ordens bastante distintas. E talvez o sentimento e o discurso do vazio advenham muito mais da sensação de perda, de fim de um certo modo de estar no mundo, de a arte e a literatura estarem no mundo, do que propriamente de uma ausência de produção cultural decorrente da repressão política e da censura. A década de 70 trará para a cena cultural, de forma mais acirrada, mesmo que silenciosa, as tensões entre as várias formas de resistência ao autoritarismo, bem como as questões que emergem da consolidação da indústria cultural. O humor, a contracultura, o "desbunde" comportamental passam a aflorar num outro discurso de resistência, mais sutil (mais eficiente?) do que o registro sério, “elevado”, que encontrávamos na Revista Civilização Brasileira,e que será reencontrado, com variações, em Opinião e Argumento.

É no vigor da imprensa alternativa que melhor podemos perceber novas mesclas culturais, especialmente nas tensões que a relação com a comunicação de massas, através das redes de televisão, vão provocar. A TV se imiscui nas publicações, primeiramente através dos que dela participam, com uma presença bastante forte dos representantes da música popular brasileira, e também com ares de resistência política, porém não mais explícita nem panfletária, e sim atingindo o campo do comportamento. Compositores, cantores, atores, autores de novelas, apresentadores de programas de auditório, todos

Congresso Nacional e suprimiu as garantias democráticas, as liberdades individuais e de expressão. Durante sua vigência (até 31 de dezembro de 1978), o cidadão perdeu o direito ao habeas corpus, enquanto os poderes do executivo foram enormemente ampliados. Sob sua égide, instaurou-se a censura prévia à imprensa.

${ }^{39}$ Silêncio, exílio, astúcia = resistência? Há um tipo de produção significante que consiste na divisão do sujeito, no silêncio, e na relação contraditória entre ser e parecer. Este universo da dissimulação, da astúcia e também da deserção tem sido chamado de resistência. Há resistência quando em um processo histórico enfrentam-se dois ou mais códigos, um dos quais é hegemônico e se identifica com a razão, a verdade, a universalidade, a lei e o centro, e põe o outro fora da lei e da razão. O menor, o subalterno, o outro, está excluído dos canais políticos e de enfrentamento e na impossibilidade de ocupar o poder; deve sobreviver na lei dominante, que conhece mas não reconhece, e apela a um tipo de produção significante que consiste na construção de duplicidades e divisões: cada vez une os dois códigos, o do outro e o próprio, e constrói a máscara de uma aliança de subordinação, mas os códigos não convergem nem se complementam segundo a figura da aliança, mas se contradizem e se negam entre si. (Ludmer 196)

${ }^{40} \mathrm{O}$ jornalista Zuenir Ventura publicou na revista Visão, em julho de 1971, artigo intitulado "O vazio cultural”, dizendo:“Alguns sintomas graves estão indicando que, ao contrário da economia, a nossa cultura vai mal e pode piorar se não for socorrida a tempo. (...) muitos intelectuais manifestaram sua decepção e pessimismo em relação ao passado recente e preocupação em relação ao futuro. A conclusão revelava que a cultura brasileira estava em crise. Contrastando com a vitalidade do processo de desenvolvimento econômico, o processo de criação artística estaria completamente estagnado. Um perigoso "vazio cultural” vinha tomando conta do país, impedindo que, ao crescimento material, cujos índices estarrecem o mundo, correspondesse idêntico desenvolvimento cultural. Enquanto nosso produto interno bruto atinge recordes de aumento, nosso produto interno cultural estaria caindo assustadoramente" (Gaspari,Hollanda e Ventura 40). 
passam pelas páginas desses periódicos, assim como escritores e figuras de importância intelectual reconhecida. Um bom exemplo dessa presença é o conjunto das entrevistas d' $O$ Pasquim, em que temos desde uma entrevista virtual com o poeta Carlos Drummond de Andrade, ${ }^{41}$ entrevistas com o crítico Alceu de Amoroso Lima, com o filólogo Antonio Houaiss, passando por entrevistas com Caetano Veloso, com Chico Buarque, com apresentadores de TV como Chacrinha (o “comunicador” popular tropicalista, protótipo de um certo kitsch com potencial crítico) e Silvio Santos, com a atriz Leila Dinis, enfim, com uma galeria variada e absolutamente desierarquizada de personagens da cena cultural, perturbadora da dicotomia entre cultura elevada e baixa cultura.

Se, como já vimos, a crítica frankfurtiana da indústria cultural era absolutamente incipiente no Brasil dos 50 anos de modernismo, ${ }^{42}$ e as idéias hegemônicas na imprensa cultural de esquerda eram as gramscianas, especialmente no que diz respeito ao "jornalismo total” e ao papel do intelectual na cultura, é preciso fazer duas ressalvas: a) a aparente desierarquização se dá preferentemente em alguns periódicos (por motivos cuja análise não cabe aqui); b) os lugares de onde determinados intelectuais falam estão problematizados. A relação entre TV e a cultura de extração erudita não é tão simplesmente dicotômica. Paradoxalmente, esse veículo de anestesia do povo abriga ao mesmo tempo defensores da aldeia global e do governo militar, e dramaturgos como Dias Gomes, ligado ao proscrito Partido Comunista, a periódicos culturais proibidos, ao teatro censurado. Dias Gomes continua enfrentando problemas com a censura ao longo dos anos 70, mas encontra na TV, através do sucesso de público, um certo espaço de sobrevivência e crítica. Como ele, muitos outros egressos do campo teatral e da esquerda terão acolhida na TV. Cooptação pelo mercado? Neutralização pelo capital? Pode ser, mas seria uma explicação muito simplista, já que não necessariamente abdicaram de militância político-artística, nem de um certo conjunto de valores que pressupõem hierarquização entre os bens culturais e estéticos, mas também a utilização dos meios de comunicação de massa como veículo de conscientização e resistência. Apesar dessas concepções, os discursos pró e contra a TV não tardam. Emergem de forma muitas vezes maniqueísta e mal ocultam os impasses que a década traz ao campo literário e acadêmico, que denunciam o "vazio" destes anos. No entanto, pode-se dizer que se tratava de um discurso sobre algo diferido, ou de um vazio que se configurará na década seguinte, quando se fará necessário constatar o inocultável.

Num outro diapasão, o lacônico editorial ${ }^{43}$ de lançamento, em 1973, da sucessora da Revista Civilização Brasileira, ou de Paz e Terra, ou de Teoria e Prática-resistência em

\footnotetext{
${ }^{41}$ Um dos últimos modernistas ainda vivo àquela altura, surge como fantasma na entrevista inventada Como o poeta enviou uma carta se recusando a conceder a entrevista por "não ter nada mais a dizer”, o jornal montou uma entrevista apócrifa a partir de trechos das obras e de declarações anteriores do poeta. Cf. O Pasquim 106 (15 jul. 1971): 3-6.

${ }^{42} 1972$ foi o ano de publicação, pela Editora Tempo Brasileiro, de um conjunto de ensaios de Adorno, dentre os quais “Engagement”, uma crítica ao conceito de arte engajada de Sartre e Brecht. Sem dúvida é possível ler, na escolha deste ensaio pelos editores, uma crítica a boa parte da esquerda brasileira e às defesas do engajamento vigentes entre nós desde os anos 60 .

${ }^{43}$ Transcrevo-o, integralmente: “A natureza social tem horror ao vácuo cultural e tende a preenchêlo de uma forma ou de outra. Uma das formas de fazê-lo é utilizando a dependência, a acomodação, o arrivismo. /A nossa pretende ser a outra forma, a que se definirá no percurso de nosso grupo. Este
} 
“registro sério"- demonstra a nova e necessária prática: usar meias palavras, abusar da elipse e da alusão. Misto de editorial e manifesto, ou declaração de princípios, o texto de abertura de Argumento define a revista, de um lado, como o espaço de atuação para intelectuais expurgados pela ditadura de seus espaços institucionais, algo como um espaço compensatório, mas também um ato de resistência ao próprio expurgo; de outro lado, a revista se define como um "outro" modo de preencher o "vácuo cultural”, o que supõe preenchimento, não vácuo; contra dependência, arrivismo, subordinação, propõe-se a independência, o inconformismo. Argumento surge como forma de resistência num momento de forte repressão política, publicada pela editora Paz e Terra, e tendo como Diretor o conhecido jornalista Barbosa Lima Sobrinho. ${ }^{44} \mathrm{O}$ ensaio de abertura do primeiro número, o hoje antológico "Literatura e subdesenvolvimento", de Antonio Candido, evidencia as diferenças de perspectiva teórico-crítica em relação ao que encontrávamos na seção de Literatura da Revista Civilização Brasileira. Nos 4 únicos números publicados -sendo que o quarto foi recolhido pela censura- cumpriu-se a função de marcar um lugar de resistência sem ataques diretos, de prática do inconformismo com a situação política vigente, e, especialmente, de colocar em circulação importantes ensaios de interpretação da cultura, que incluem colaborações estrangeiras como as de Angel Rama, John Kenneth Galbraith, e Thomas Skidmore. Além dos membros dos Conselho de Redação e Consultivo -intelectuais da maior importância-, colaboram ainda em Argumento Roberto Schwarz, Celso Lafer, Antonio Callado, Gilda de Mello e Souza, Jean-Claude Bernadet, Davi Arrigucci Jr., Hélio Jaguaribe, Otto Maria Carpeaux, Flávio de Carvalho, João Luiz Lafetá, Ismail Xavier, Arnaldo Pedroso d’Horta, Heloísa Buarque de Hollanda, Antonio Carlos de Brito (o poeta Cacaso), dentre outros. Sem dúvida, trata-se da revista mais

é vário na idade e na preocupação, mas se unifica no entendimento em criar um veículo novo para o que há de vivo, válido e independente na circunstância cultural brasileira; e um ponto de encontro com o pensamento de outras terras, notadamente as do continente. / Os obstáculos que eventualmente encontrarmos e os estímulos que recebermos serão igualmente indicativos da utilidade de nossa função. Muito intelectual brasileiro foi arrancado de seu mundo e é preciso que encontre um terreno onde possa novamente se enraizar. A limitação de nosso campo poderá ainda ser restringida, mas sempre haverá um papel a ser cumprido pelo intelectual que resolva sair da perplexidade e se recuse a cair no desespero. / Nascemos sem ilusões e não está em nosso programa nutri-las. A independência custa caro e não encoraja as subvenções. Não temos propriamente o que vender mas nos achamos em condições de propor um esforço de lucidez. Este não é artigo de luxo ou de consumo fácil mas em qualquer tempo é alimento indispensável para pelo menos alguns. Sua raridade é, aliás, sempre provisória; tudo que a lucidez revela tende a se transformar em óbvio. / Contra fato há argumento.” Analisei este editorial bem como outros aspectos desta revista em outro artigo (1:1)

${ }^{44}$ O Conselho de Redação é composto por: Anatol Rosenfeld, Antonio Candido, Celso Furtado, Fernando Henrique Cardoso, Francisco Weffort, Leôncio Martins Rodrigues, Luciano Martins e Paulo Emílio Salles Gomes. Do Conselho Consultivo participam Érico Veríssimo, Florestan Fernandes, Paulo Duarte, Sérgio Buarque de Holanda, Simão Mathias (Brasil), Anibal Pinto, Octavio Paz, Torcuato de Tella (América Latina), Albert Hirschman, Brian Van Arkadie e Dudley Sears (Europa e EUA). Argumento mantém um diálogo, para não dizer parceria, de colaboradores e textos com o semanário alternativo Opinião, que faz a resistência cultural “séria”, para não dizer sizuda, distanciando-se portanto do Pasquim 
importante da primeira metade dos anos 70 , mesmo sendo uma das únicas. ${ }^{45}$ Sem dúvida aqui nos mantemos ainda no campo da cultura “elevada”, da arte, sem misturas com a indústria cultural de massa, cumprindo, de certo modo, o programa da Civilização Brasileira,sem os sectarismos ideológicos. Por outro lado, Argumento não dialoga com a irreverente Bondinho, sustentada e distribuída pela rede de supermercados Pão de Açúcar, nem com a única e exclusiva pós-tropicalista e pós-concretista Navilouca. Os desbundes comportamentais e as coisas do corpo revalorizado passam ao largo da racionalista Argumento.

E AGORA, JOSÉ?

Quem se lembra de Escrita, Escrita Ensaio, José, Encontros com a Civilização Brasileira, Almanaque, Inéditos, Código, Poesiaem G, Ficções, Através, Qorpo Estranho, Polímica, Oitenta, Bondinho, Malasarte, Ânima, Revista de Poesia e Crítica, Leia Livros, além, é claro, dos tablóides, Movimento, Versus, Beijo? O rol aleatoriamente construído aponta para a diversidade de projetos e de realizações. Pluralidades. Heterogenias. Não é por acaso que na segunda metade da década de 70 se concentram seus lançamentos: marcam um período de transição na história cultural brasileira, em que coexistem um processo de “destape”, ou de desrepressão, mais voltado ao passado, e outro de introdução de novas rotas de vôo, mesmo que um tanto tortuosas ou com múltiplos rumos, seja no campo da política, seja no dos costumes, seja nos campos intelectual e literário.

Linhagens críticas e literárias formadas nas décadas anteriores se consolidaram, outras se constituíram, se dispersaram, se reagruparam, se opuseram. Valores críticos e estéticos foram revistos e pontuados, freqüentemente, pela discussão sobre o papel e a função do intelectual, da literatura e das artes num cenário político-social em mutação, no qual as relações com a sociedade de consumo e a cultura de massa não podem mais ser ignoradas. Processos de mudança, de fim de século, que se explicitam na trama dos discursos que tecem a diversidade dos periódicos.

Lançada em 1976, a revista Josét6 estampa na capa de seu primeiro número um retrato do "poeta maior", Carlos Drummond de Andrade; obviamente, lembrar que o título da revista é o mesmo do “célebre poema” de Drummond é pura redundância. Sob a foto do poeta, a chamada: “DRUMMOND: poemas eróticos”, talvez uma estratégia de vendagem. Na mesma capa, em foto menor e à direita de Drummond, outra foto de outro poeta, Haroldo de Campos. Reavaliações?

\footnotetext{
${ }^{45}$ Além de Tempo Brasileiro e, Convivium, oriundas da década anterior, e dos jornais alternativos, cabe registrar o Boletim de Ariel (título de uma revista da década de 30), lançado provavelmente em 1973 por Afrânio Coutinho e que, longe de exercer qualquer resistência ao governo militar prestase a fazer elogios ao presidente Médici. Sobre esta revista, Argumento publica em seu último número uma notinha mordaz e irônica, assinada P.E. (Paulo Emílio Salles Gomes), que, entre outras ironias, diz: "O novo boletim tem pouco de Ariel e ficaria melhor denominado Boletim de Afrânio Coutinho" (4:159).

${ }^{46}$ Um estudo sobre José pode ser lido na dissertação de mestrado de Simone Dias, agora publicada em livro (Dias, 2001).
} 
Ao citar o poema de Drummond, o título da revista a insere inequivocamente no campo da poesia modernista canônica, tomada como referencial e valor. Tal inserção nos valores modernistas pode ser lida e confirmada também em outros muitos signos, inclusive na homenagem póstuma a Otto Maria Carpeaux no 10e e último número da revista, que se traja de negro para estampar a foto em close do intelectual recentemente falecido. Luto pelas várias mortes: a de Carpeaux e a da revista e, com elas, a de todo um mundo que se pautava, de um lado, pelos valores do "alto modernismo", de outro, pela resistência.

A convivência, que é também o confronto, entre os valores modernos e modernistas, com a surgimento de novas determinantes culturais -desintelectualização, contracultura, indústria cultural, mídia-, colocam-se na e para a revista como impasse, como dilema insolúvel. Parece ser essa a verdadeira crise, discutida em dois debates que a revista promove e publica. No primeiro, ${ }^{47}$ sobre a "poesia marginal”, discutiu-se, como ainda se discute, a oposição entre cultura e descultura, e não mais entre engajamento ou alienação.

No segundo debate -“José no espelho” (9: 2-17)-, os escritores Ferreira Gullar, Silviano Santiago, Geraldo Carneiro e Luiza Lobo reúnem-se com o conselho editorial de José, Luiz Costa Lima, Gastão de Holanda, Jorge Wanderley e Sebastião Uchoa Leite, para não apenas discutir os problemas de uma revista literária, mas especificamente para discutir os rumos de José. Opiniões divergentes são expostas e as soluções possíveis para a sobrevivência do veículo também são distintas. O debate aborda a dificuldade de se construir um periódico que não seja porta-voz de um grupo homogêneo e não manifeste um posicionamento político. Quais seriam os critérios de edição dos textos, de vendagem, como concorrer com outras revistas e suplementos literários, que linguagem adotar, como definir o público leitor? A questão do valor literário se acrescenta e se mescla à do mercado. José pode ser lida como o signo do moderno e de suas impossibilidades de permanência após o esgotamento das vanguardas. José vive o dilema em sua nostalgia do moderno e a ele sucumbe, não sem deixar saudades e alguns parentescos, como é o caso da mineira Inéditos, que contava com Wander Piroli, Murilo Rubião, Roberto Drummond, Henry Correa de Araújo e Jaime Prado Gouveia em seu Conselho Editorial .

Apontada no segundo debate como uma das revistas concorrentes, mas também como um modelo recusado por e para José, a revista Escrita, que à época apresentava tiragens de cerca de 15.000 exemplares distribuídos em todo o Brasil (enquanto José mal conseguia vender 3.000 em tiragens de 5.000), era considerada pelos editores de José como uma revista ligada ao mercado, mesmo que editorial. De fato: Escrita lutava pela profissionalização do escritor e pela divulgação literária, ocupando um lugar muito próximo ao do "jornalismo literário", ou melhor, ao lugar da informação / promoção jornalística da literatura. Possuía um sistema de correspondentes por todo o país, que mandavam notícias de suas regiões -sobre novos escritores, lançamentos de livros, eventos literários, etc.- e ajudavam a divulgar localmente a própria revista. Escrita

\footnotetext{
${ }^{47}$ Publicado com o título "Debate: poesia hoje” (2: 2-9), tem por mote a antologia 26 Poetas Hoje, organizada por Heloísa Buarque de Hollanda, que deu maior visibilidade ao que se convencionou chamar "poesia marginal dos anos 70". Deste debate participaram, além de Heloísa, poetas incluídos na antologia (Eudoro Augusto, Geraldo Carneiro e Ana Cristina Cesar) e representantes da redação da Revista (Luiz Costa Lima, Jorge Wanderley e Sebastião Uchoa Leite).
} 
promovia ainda grandes concursos literários, divididos por gêneros, mantinha forte seção de correspondência dos leitores, publicava poemas e contos, especialmente de novos autores, além de resenhas e muitas, muitas entrevistas. O ensaio crítico não tem lugar na revista; ou melhor, ocupa um espaço à parte, uma espécie de "suplemento": EscritaEnsaio.

Dentre as bandeiras de luta de Escrita destacam-se a busca da ampliação do mercado editorial para o escritor brasileiro, através de uma desejada ampliação do público leitor, o que leva a revista a eleger a televisão como o principal inimigo, o entrave maior para a consecução de seus objetivos. Importava, portanto, divulgar "a” literatura, divulgando os escritores e seus livros, sem defender, no entanto, uma ou outra corrente literária específica, ou valores pré-determinados. Assim, Escrita não traz em suas páginas grandes polêmicas estéticas, e as discussões são travadas muito mais entre diferentes colaboradores, ou como reação de leitores a eventuais matérias publicadas. A discussão sobre o valor literário, ou sobre a qualidade estética de novas obras, ou ainda sobre o lugar e o sentido da nova poesia dos 70, não é matéria em que se engaje a revista. O importante era mostrar, divulgar, entrevistar, agitar. E assim Escrita sobreviveu por 39 números, adentrando os anos 80 .

Embora não possa ser estritamente classificada como um periódico acadêmico, Almanaque-cadernos de literatura e ensaio, que teve 14 números editados pela então poderosa Editora Brasiliense, que também publicava o tablóide Leia Livros. Era o veículo para um grupo bem definido de intelectuais das áreas de letras e filosofia da USP, ligados a Antonio Candido, e cujos nomes falam por si: Walnice Nogueira Galvão e Bento Prado Jr a dirigiam, com a colaboração estreita de Lígia Chiappini Moraes Leite e Roberto Schwarz. Diferentemente de Escrita, não tinha pretensões de fazer divulgação literária. Mas publicou também textos híbridos, paródicos, satirizando especialmente o que considerava as "modas teóricas”, ou, em outras palavras, a voga estruturalista. Uma questão acadêmica, é certo, mas em outro diapasão. Reencontramos aqui, mais uma vez, a discussão política e o debate sobre o lugar do intelectual e do artista: como massificar sem degradar? Como preservar valores elevados e qualidade estética sem elitizar?

É possível afirmar que Almanaque compartilhava com José o apreço pelos valores estéticos herdados do modernismo e com Argumento uma certa retórica de resistência e de engajamento político; no entanto, as duas primeiras distinguiam-se entre si pelos grupos que as constituíam, pelas cidades em que se localizavam, pelas posições críticoteóricas que defendiam. Afinal, dentre os que faziam a revista carioca estavam os criticados pela revista paulista. Na falta de outro, um bom motivo para José desejar distinguir-se de Almanaque, que mais ironizava do que discutia as divergências.

Embora não se explicite em "José no espelho”, cabe ainda marcar as diferenças entre José, Escrita e Almanaque, de outros dois grupos de revistas da época, que marcavam duas tendências culturais opostas: de um lado, revistas como Código, Corpo Extranho (ou Qorpo Estranho), que se completariam ainda em Através e Polímica, todas nitidamente engajadas no experimentalismo concretista, assumindo o papel de divulgadoras, legitimadoras e, por que não, de conservadoras daquela tendência estética e de seus idealizadores; de outro lado, revistas como Pólem, Muda e Nuvem Cigana, ou ainda o jornal-revista Beijo, dentre outras, afinadas às modas contraculturais e centradas na 
produção de alguns dos novos poetas dos anos 70. Um cenário plural, sem dúvida, em que todos sucumbiram.

SEDUÇÃO DA MEMÓRIA

De algum modo, os anos 70, no Brasil, não foram apenas anos de ascensões e quedas rápidas. Foram anos de passagens, de fechamento de ciclos, foram os anos do fim do moderno como "futuro presente". Esta categoria, utilizada por Andreas Huyssen para caracterizar a cultura modernista nos países do hemisfério norte ocidental, se aplica perfeitamente bem não apenas à cultura construída pelo modernismo brasileiro, mas também e especialmente às suas últimas manifestações (variantes epigonais?), como é o caso da auto-intitulada vanguarda brasileira, isto é, o concretismo. Esta idéia de um “futuro presente"descreve perfeitamente bem auto-imagem recorrente, o amplo imaginário nacional que se vê potencialidade ainda não realizada: Brasil, o país do futuro. E, certamente, é a impossibilidade de manter tal representação diante das novas circunstâncias vividas e escritas que o ciclo se fecha. E, ainda me valendo de Huyssen, o "passado presente” precisa ser construído como forma de ocupar a verdadeira lacuna: a do futuro.

Seduzidos pela memória, oscilando entre o sentido de raridade e a documentação histórica, o hoje se confronta com o passado. Vejamos um sintoma.Em março de 1979 era lançada em são Paulo, pelo Centro de Estudos da arte Contemporânea, uma nova revista cultural: Arte em Revista, coordenada por dois professore da USP, Otília Beatriz Fiori Arantes e Celso Favaretto, e pelo jornalista cultural Matinas Susuzki Júnior, da Folha de S.Paulo. Em geral, o que se espera de uma nova revista cultural é que apresente o novo, o que está efetivamente ocorrendo no campo das artes: novos artistas, novas tendências, novas perspectivas que se avizinham, ou ainda as maiores preocupações da sua contemporaneidade, do seu momento. Curiosamente, o que essa nova revista traz, inclusive na capa de seus dois primeiros números, vestida de cor única, verde-escuro, é apenas um título: “anos 60”. ${ }^{8}$ Seu propósito?

Arte em Revista pretende divulgar documentos que possam servir de subsidio para repensar a arte e a história brasileira: textos de análise e manifestos esgotados ou de difícil acesso-, ao lado de entrevistas e depoimentos inéditos de artistas e críticos. Para entender o que se passa hoje no Brasil, no domínio das artes, é necessário se reportar a nossa tradição artística e, de forma mais imediata, à efervescência cultural e política dos anos 60. Foi o que motivou o CEAC a iniciar suas atividades por uma ampla pesquisa e um estudo crítico daquele decênio e a dedicar-lhe os primeiros números de Arte em Revista. (1:1) [grifos meus].

O que ficou da resistência de outros tempos? Por que voltam Glauber e sua estética da fome? Os “manifestos” do Teatro de Arena, do Opinião, do Oficina, do CPC? Antonio

\footnotetext{
${ }^{48} \mathrm{O}$ mesmo título e a mesma diagramação se repetem no número 2, variando apenas a cor do fundo, agora em azul-marinho.
} 
Candido, Haroldo de Campos, Anatol Rosenfeld, Paulo Emílio Salles Gomes, Poesia concreta; Música Nova, Tropicália, canção de protesto; Rex Time. Tudo volta, agora como documento, resistência sem objeto, peça de museu exposta na galeria, mercadoria revalorizada. No final dos 70, de volta aos 60, em busca de um tempo perdido, de uma utopia impossível. Chegamos ao limiar da “década perdida”.

BibLIOGRAFÍA

Antelo, Raúl. Literatura em revista. São Paulo: Ática, 1985.

Brasil: nunca mais. Petrópolis: Vozes, 1985.

Cabral, Sergio et al. “Aqui está a entrevista de Drummond”. O Pasquim 106 (15 jul., 1971): 3-6.

Camargo, Maria Lucia de Barros. “Resistir: quem há de?” Declínio da arte, ascensão da cultura. Raúl Antelo, org. Florianópolis: ABRALIC: Letras Contemporâneas, 1998. 169-176.

Campos, Augusto de. Balanço da Bossa. 2ª ed. São Paulo: Perspectiva: 1974.

Carpeaux, Otto Maria. "Estruturalismo é o ópio dos literatos”. Revista Civilização Brasileira III/14 (julho 1967): 245-250.

Dias, Simone. Continuidades efêmeras: a crise do intelectual legislador e a ascensão do intérprete. Chapecó: Argos, 2001.

Favaretto, Celso F. Tropicália: alegoria, alegria.São Paulo: Kairós, 1979.

Félix, Moacyr (org.). Ênio Silveira:arquiteto de liberdades. Rio de Janeiro: Bertrand Brasil, 1998.

Gaspari, Elio. A ditadura envergonhada. São Paulo: Companhia das Letras, 2002.

, Heloisa Buarque de Hollanda e Zuenir Ventura. Cultura em trânsito: da repressão à abertura. Rio de Janeiro: Aeroplano Editora, 2000.

Gomes, Dias. “O Berço do herói e as armas do Carlos”. Revista Civilização Brasileira I/ 4 (set. 1965): 257-268.

Gullar, Ferreira. "Problemas estéticos na sociedade de massa”. Vanguarda e subdesenvolvimento. Ensaios sobre arte. 3 ed. Rio de Janeiro: Civilização Brasileira, 1984. 101-143.

Huyssen, Andréas. Seduzidos pela memória. Sérgio Alcides, trad. Rio de Janeiro: Aeroplano, 2000.

Kucinski, Bernardo. Jornalistas e revolucionários: nos tempos da imprensa alternativa. São Paulo: Escritta Editorial, 1991.

Ludmer, Josefina. O gênero gauchesco: um tratado sobre a pátria. Antonio Carlos Santos, trad. Chapecó: Argos, 2002.

Mota, Carlos Guilherme. Ideologia da cultura brasileira. 8ª ed. São Paulo: Ática, 1994.

Ortiz, Renato. A moderna tradição brasileira: cultura brasileira e indústria cultural. São Paulo: Brasiliense, 1988.

P.E. “Boletim de Ariel”. Argumento I/4 (fevereiro, 1974): 159.

Proença, M. Cavalcanti. "Poesia Brasileira, 1964”. Revista Civilização Brasileira I/1 (março, 1965): 161-176. 
Revista Civilização Brasileira. "Princípios e propósitos”. Revista Civilização Brasileira I/1 (março, 1965): 3-4.

Rocha, Glauber. “Uma estética da fome.” Revista Civilização Brasileira I/3 (julho, 1965): 165-169.

Silveira, Ênio. “Primeira epístola ao Marechal: sobre o Delito de Opinião”. Revista Civilização Brasileira I/3 (julho, 1965): 3-11.

Sodré, Nelson Werneck. “Prosa brasileira em 1964: balanço literário”. Revista Civilização Brasileira I/1 (março, 1965): 146-160.

"Notas de crítica”. Revista Civilização Brasileira I/2 (maio, 1965): 155-169. “O momento literário”. Revista Civilização Brasileira I/4 (set. 1965): 167-188. “O momento literário”. Revista Civilização Brasileira I/7 (maio, 1966): 159-166. “O momento literário”. Revista Civilização Brasileira I/8 (julho 1966): 147-151. “O momento literário”. Revista Civilização Brasileira III/14 (jul. 1967): 171-180. “O momento literário”. Revista Civilização Brasileira III/18 (março-abril, 1968): 129-140.

Williams, Raymond. Cultura. Trad. Lólio Lourenço de Oliveira. Rio de Janeiro: Paz e Terra, 1992.

\section{Periódicos Citados}

Almanaque-Cadernos de Literatura e Ensaio. São Paulo, 1976-1982.

Argumento. Rio de Janeiro, 1973-1974.

Arte em Revista. São Paulo, 1979-1984.

Através. São Paulo, 1978-1979.

Beijo. Rio de Janeiro, 1977-1977.

Boletim de Ariel. Rio de Janeiro, 1973-1975.

Bondinho. São Paulo, 1970-1972.

Código. Salvador, 1974-1989.

Convivium. São Paulo, 1962-1988 (?)

Encontros com a Civilização Brasileira. Rio de Janeiro, 1978-1981.

Escrita. São Paulo, 1975-1988.

Escrita Ensaio. São Paulo, 1977-1982.

Inéditos. Belo Horizonte, 1976-1977.

Invenção. São Paulo, 1962-1967.

José. Rio de Janeiro, 1976-1978.

Leitura. Rio de Janeiro, 1942-1948; 1954-1968.

Movimento. São Paulo, 1975-1981.

Navilouca. Rio de Janeiro, 1972.

Opinião. Rio de Janeiro, 1972-1976.

O Pasquim. Rio de Janeiro, 1969-1989.

Paz e Terra. Rio de Janeiro, 1966-1969.

Pif-Paf. 1964-1964.

Poesia em G.

Polímica. São Paulo, 1979-1982. 
Práxis. São Paulo, 1962-1966.

Revista Civilização Brasileira. Rio de Janeiro, 1965-1968.

Revista do Livro. Rio de Janeiro, 1956-1970.

Tempo Brasileiro. Rio de Janeiro, 1962-1998 (?)

Teoria e prática. 1967-1968.

Versus. 1975-1979.

Visão. Rio de Janeiro, 1959-1994. 